\title{
後半規管神経刺激により前庭神経四亜核内に発生する 細胞外電場電位
}

\author{
聖マリアンナ医科大学耳鼻咽喉科学教室（主任：竹山 勇教授) \\ 中 島 博 昭
}

\author{
EXTRACELLULAR FIELD POTENTIALS IN THE FOUR VESTIBULAR \\ SUBNUCLEI EVOKED BY STIMULATION OF THE AMPULLARY NERVE \\ OF THE POSTERIOR SEMICIRCULAR CANAL IN CATS
}

\author{
HIROAKI NAKASHIMA, M.D.
}

Department of Otolaryngology, St. Marianna University School of Medicine, Kawasaki

Changes in amplitudes of the field potential complex, $P, N_{1}$, and $N_{2}$, in the ventrodorsal direction were studied in four vestibular subnuclei following stimulation of the ampullary nerve of the posterior semicircular canal in anesthetized cats. The $P, N_{1}$, and $N_{2}$ potentials represent the spike potentials of the primary vestibular nerve fibers, and the monosynaptically and polysynaptically evoked spikes of the vestibular neurons, respectively. These complex potentials were recorded in four vestibular subnuclei. Large amplitudes of $P, N_{1}$, and $N_{2}$ potentials were recorded in localized areas, i. e., the central part of the medial nucleus, the ventral $1 / 3$ of the descending nucleus, and the ventral $1 / 3$ of the superior nucleus, respectively. Latency analysis of the $\mathrm{P}$ potential suggested that the ascending branches in the superior nucleus are thinner than the descending branches in the descending nucleus.

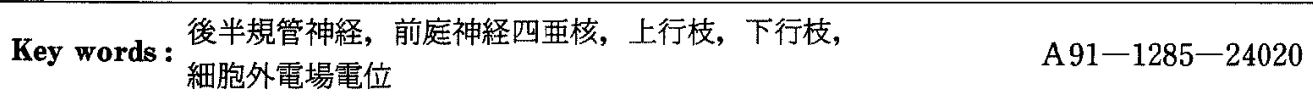

\section{はじめに}

前庭一次求心性線維の主要投射部位は前庭神経核の 四带核，すなわち上核・下核・内側核・外側核であり， その他Yグループ, 小脳の片葉・小節葉・虫部垂・室 頂核や，外転神経核とその外側部網様体，副楔状束核 の外側部網様体へも投射している ${ }^{1556)(7) 17)}$.

Gacek $^{3)}$ はネコを, Stein and Carpenter ${ }^{12)}$ はサルを 用いて，前庭神経節の限局した部位を破壊する方法に 上り，個々の半規管・耳石器に由来する前庭一次求心 性線維の投射部位について実験を行っている，それら の研究によると，種による差異は少なく，半規管由来 の一次求心性線維は外側核のレベルで前庭神経核に入
り，上行枝と下行枝に分かれ，上行枝のうち前半規管 と外側半規管に由来する線維は上核の吻側部に, 後半 規管由来の線維は上核尾側中央部に投射するという. また，すべての下行枝は外側核加ら下核を下行し，外 側核・下核・内側核に投射している. 耳石器由来の一 次求心性線維のうち, 卵形蛮由来の線維は内側核・下 核・外側核腹側に, 球形整由来の線維は主にYグルー プと下核に投射し, 耳石器系一次求心性線維は半規管 由来の神経線維と異なり, 前庭神経内カハル間質核と 上核には側枝を出さない3).

最近, 半規管系由来の前庭一次求心性線維の投射様 式が Horseradish Peroxidase (HRP) の軸索内注入法 
を用いて研究された。1982年, Mannen ${ }^{4 / 8)}$ は自然刺激, あるいは個々の半規管神経の選択的電気刺激法によ り, 入力様式を同定した単一前庭一次求心性線維に HRP を注入し, その走行と投射部位について詳細に 調へ，1）前半規管と外側半規管由来の線維は前庭神 経の吻側を, 後半規管由来の線維は尾側を走り, 前庭 神経内カハル間質核に側枝を出した後, 外側核腹外側 部で上行枝と下行枝に分かれる。２）上行枝及び下行 枝は外側核から内側核へ向かう側枝を出し，終末を外 側核及び内側核に作る。3）前半規管と外側半規管由 来の上行枝は上核全体に投射するが，後半規管由来の 線維は主に上核尾側中央部に投射する。4）いずれの 下行枝も下核腹外側を下行し, 内側核に数本の側枝を 直角に出す. 前半規管由来の側枝は下核, 内側核に広 く投射しているが, 後半規管由来の側枝は, 下核外側 部, 内側核中央部の比較的限局した部位に投射し，水 平半規管由来の分枝投射様式は，その中間の拡がりを 示すことなどを明らかにした.

前庭一次求心性線維を電気刺激すると, 一次求心性 線維の活動によるP波, 前庭核ニューロンの単シナプ ス性放電による $\mathrm{N}_{1}$ 波と主に多シナプス性放電による と考えられる $\mathrm{N}_{2}$ 波が前庭神経核内で記録できる9. $\mathrm{P}$ 波の頂点, 及び $\mathrm{N}_{1}$ 波, $\mathrm{N}_{2}$ 波の始まりの潜時はそれぞ れ $0.66 \pm 0.14 \mathrm{~ms}, 1.06 \pm 0.22 \mathrm{~ms}, 2.46 \pm 0.26 \mathrm{~ms}$ で9), 最 大振幅を示す部位は内側核腹側部である ${ }^{11)}$.

一方, 球形䨳由来の前庭一次求心性線維のみを電気 刺激した場合, $\mathrm{P}$ 波は不明瞭で, $\mathrm{N}_{1}$ 波の振幅は小さ $く, \mathrm{~N}_{1}$ 波の始まりの潜時は $0.9 \sim 1.9 \mathrm{~ms}$ で, 頂点までの 潜時は 1.2〜 2.5ms と半規管神経を含む刺激により発 生する $\mathrm{N}_{\mathrm{L}}$ 波の潜時に比して遅いことが示されてい $3^{18)}$.

半規管神経を選択的に電気刺激し前庭神経四重核内 でどのような $\mathrm{P}$ 波， $\mathrm{N}_{1}$ 波， $\mathrm{N}_{2}$ 波が発生するかについ ては検討されていない，そこで今回，ネコを用いて， 後半規管神経を選択的に電気刺激することにより前庭 神経四亜核内に発生する $\mathrm{P}$ 波, $\mathrm{N}_{\mathrm{t}}$ 波, $\mathrm{N}_{2}$ 波の振幅, 潜時等についての知見を得たので報告する。

\section{実験方法}

Ketamine Hydrochloride (50mg/kg i.m. PARKEDAVIS) 及び Pentobarbital Sodium ( $5 \mathrm{mg} / \mathrm{kg}$ i.p. Abbott Laboratories) で麻酔した 8 匹の成ネコ(体重 2.0-3.0kg）を使用した。麻酔後, 気管切開を行い気管 カニューレを㨉入し, 血圧測定, 及び楽剤投与のため
カニューレを各々大腿動脈と, 大腿静脈に㨂入した。 斜め後腹側より鼓室胞を開放し, 正円空尾側の後半䊎 管膨大部に小孔を開け, 後半規管神経を刺激するため に電極を刺入した。また, 顔面神経直下の前半規管及 び外側半規管膨大部にも小孔を開け, 両半規管神経を 刺激するために電極を刺入した ${ }^{13)}$. 刺激用電極は, 直径 $100 \mu \mathrm{m}$ のステンレス線を 2 本張り合わせ, 先端を切り そろえたものを使用した。半規管神経が正確に刺激さ れていることは， $0.2 \mathrm{~ms} の$ 矩形波電流を $300-400 \mathrm{~Hz}$ て 30 発通電し誘発される眼球運動を観察することにより 確認した2\}. 前庭神経すべてを刺激するために, 銀ボー 儿電極を正円空, 卵円空に挿入し, 電流滑走と乾燥加 ら神経を保護するためパラフィン・ワゼリン混合液を 鼓室胞内に満たし，各電極を歯科用セメントで固定し た。

Pancronium Bromide (Organon) にて非働化後, 人工呼吸を施行した。前庭神経核から電場電位を記録 するために後頭骨を鉗除し, 小脳中央部を吸引除去し, 第 4 脳室底を露出した. 電場電位は, 電極を背側より 前庭神経核内に刺入し, 腹側から始めて背側に $200 \mu \mathrm{m}$ 毎に動かして記録を行った。記録用電極にはFast Green FCF を飽和させた $2 \mathrm{M} \mathrm{NaCl}$ 溶液を充満して抵 抗 $1 \mathrm{M} \Omega$ 程度としたガラス管微小電極を使用した。記 録後通電により電極先端より色素を流出させ, 記録部 位を同定した ${ }^{14)}$.

実験終了時, 致死充分量の Pentobarbital Sodium を静注し, 脳幹を摘出して $10 \%$ ホルマリンで固定後, $100 \mu \mathrm{m}$ の連続凍結切片を作成し, 切片標本に Nissle 染色を行い, 記録部位について組織学的に検討した。

\section{結果}

1. 刺激強度と細胞外電場電位の成熟

図 1 は, 後半規管神経の刺激強度を徐々に強くした 時, 前庭神経核内に発生した電場電位の成熟を表し, 横軸は刺激強度 $\left(\times \mathrm{N}_{1} \mathrm{~T}\right)$, 縦軸は振幅 $(\mu \mathrm{V})$ を示し ている. 前庭一次求心性線維の活動電位である $\mathrm{P}$ 波と 前庭二次ニューロンの発火による $\mathrm{N}_{1}$ 波の発生閥值が ほほ等しいことから， $N_{1}$ 波の発生しはじめる閥值， $N_{1}$ $\mathrm{T}$ をって後半規管神経電気刺激の闇值とし, 刺激強 度をその倍数で表した ${ }^{11)}$.

$\mathrm{N}_{1}$ 閾值の 4-5 倍の強度で前庭神経核内に発生す る細胞外電場電位は最大となり, $\mathrm{P}$ 波は $200 \mu \mathrm{V}, \mathrm{N}_{\mathrm{t}}$ 波 は $300 \mu \mathrm{V}, \mathrm{N}_{2}$ 波は $140 \mu \mathrm{V}$ に達し飽和している。

2. 後半規管神経刺激と電流滑走 


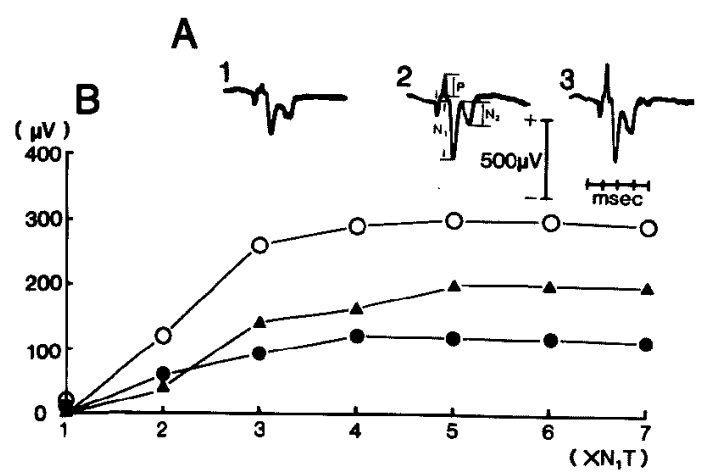

図 1 後半規管神経刺激により前庭神経核内に発 生する電場電位と刺激強度

A : 後半規管神経の刺激による電場電位. 刺 激時点を下向矢印で示し，最初の陽性波を P波，続く 2 つ陰性波を $\mathrm{N}_{1} \cdot \mathrm{N}_{2}$ 波とす る $^{9)}(\mathrm{A}-2)$.

$\mathrm{A}-1,2,3$ の刺激強度は各々 $2 \times, 3 \times$, $5 \times \mathrm{N}_{1} \mathrm{~T}$.

$\mathrm{B}$ : 電場電位各要素の振幅を繸軸に, 刺激強 度を横軸に示す。白丸は $\mathrm{N}_{1}$ 波，黒丸は $\mathrm{N}_{2}$ 波，黒三角はP波の振幅を示す。

半規管の選択的電気刺激の場合，電流滑走のために 他の半規管神経も刺激している可能性を考えなければ ならない。

図 2 は後半規管神経電気刺激により発生した $\mathrm{N}_{1}$ 波 の振幅, 前・外側半規管神経電気刺激により発生した $N_{1}$ 波の振幅，及び後半規管神経と前・外側半規管神経 の同時刺激により発生した $\mathrm{N}_{1}$ 波の振幅を各々示した ものである. $\mathrm{N}_{1}$ 波の振幅としては電位の変化点より $\mathrm{N}_{1}$ 波の頂点までを測定した（図 1. $\mathrm{A}-2$ ）。この実

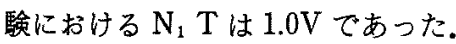

後半規管神経及び前 - 外側半規管神経同時刺激によ り発生した $\mathrm{N}_{1}$ 波の振幅は $2.5 \times \mathrm{N}_{1} \mathrm{~T}(2.5 \mathrm{~V})$ までの刺 激強度において, 各々の選択的刺激により発生した $\mathrm{N}_{1}$ 波の振幅の算術和とほ等しいが， $3 \times N_{1} T$ (3. $0 \mathrm{~V})$ 程度以上の刺激強度では算術和よりもやや小さか った。この実験では $3 \times N_{1} \mathrm{~T}(3.0 \mathrm{~V})$ 以上の刺激強度 で後半規管神経を刺激した時に，他の前庭神経に電流 滑走を起こしている可能性のあることが示唆された。

3. 前庭神経核各严核に扔ける電場電位

図 3 から図 6 は同一のネコ $\left(\mathrm{N}_{1} \mathrm{~T}=0.5 \mathrm{~V}\right)$ を用い, 後半規管神経を $5 \times N_{1} \mathrm{~T}(2.5 \mathrm{~V})$ 及び $2 \times \mathrm{N}_{1} \mathrm{~T}(1.0 \mathrm{~V})$ で刺激したとき，前庭神経四覀核内で記録された $\mathrm{P}$, $\mathrm{N}_{1}, \mathrm{~N}_{2}$ 波の振幅の推移を示している。较軸は電極の位 置，横軸は振幅を $\mu \mathrm{V}$ であらわす.

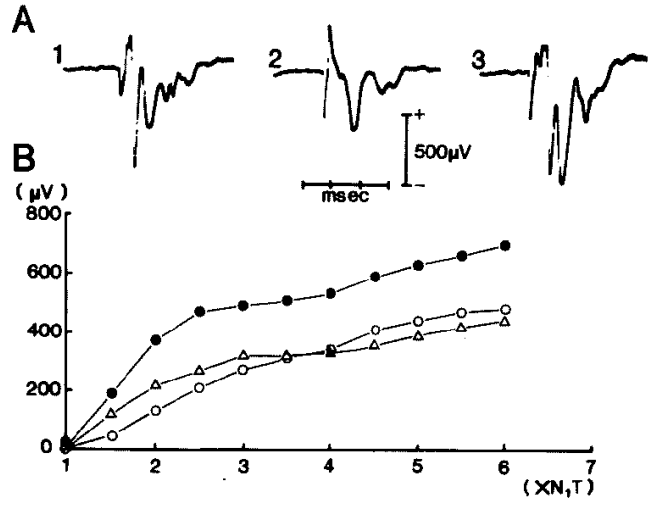

図 2 半規管神経刺激の強度と電流滑走

A：前庭神経核に発生した電場電位. A-1 は後半規管神経を $4 \times N_{1}$ T で, A - 2 は 前・外側半規管神経を $4 \times \mathrm{N}_{1} \mathrm{~T}$ で, $\mathrm{A}-3$ は後半規管神経及び前・外側半規管神経を 同時に $4 \times \mathrm{N}_{1}$ T で刺激した時の電場電位.

$\mathrm{B}$ ：横軸に刺激強度, 維軸に $\mathrm{N}_{1}$ 波の振幅を 示す. 白丸は後半規管神経刺激による $N_{1}$ 波，白三角は前・外側半規管神経刺激に上 る $\mathrm{N}_{1}$ 波, 黒丸は後半規管神経及び前・外側 半規管神経同時刺激により発生する $\mathrm{N}_{1}$ 波 の振幅の変化を示す。

\section{1）外側核に発生する電場電位}

図 3-B は $5 \times \mathrm{N}_{1} \mathrm{~T}$ と $2 \times \mathrm{N}_{\mathrm{I}} \mathrm{T}$ の強度で後半規管 神経を刺激した時の $\mathrm{N}_{1}$ 波の振幅を示したものであ る. $5 \times N_{1} \mathrm{~T}$ で後半規管を刺激すると $\mathrm{N}_{1}$ 波の振幅は 背部で $190 \mu \mathrm{V}$ であったが，腹側に行くに従い増大し， 腹側端より約 $800 \mu \mathrm{m}$ 背側で最大となり $760 \mu \mathrm{V}$ の値 を示した。さらに腹側に進むと振幅は急激にその大き さを減じた， $2 \times N_{1} T$ の刺激でも同様の推移を示し た.すなわち,腹側端より約 $800 \mu \mathrm{m}$ 背側部に後半規管 神経からの最大入力があることを示している.

次に $\mathrm{N}_{2}$ 波の振幅の推移についても $5 \times \mathrm{N}_{1} \mathrm{~T}$ と $2 \times \mathrm{N}_{1} \mathrm{~T}$ の強度で刺激し㭘討した（図 $3-\mathrm{C}$ ). $5 \times$ $\mathrm{N}_{1} \mathrm{~T}$ の刺激では背側部から中央部にかけて 20-80 $\mu \mathrm{V}$ と小さく，腹側にさらに進むと振幅はやや增大し， $N_{1}$ 波と同様，腹側端より約 $800 \mu \mathrm{m}$ 背側の部位で $340 \mu \mathrm{V}$ と最大値となり，それより腹側では振幅は小さくなっ た、また， $2 \times \mathrm{N}_{1} \mathrm{~T}$ の强度で刺激すると背側部で $20 \mu \mathrm{V}$ ，中央部で最大值 $160 \mu \mathrm{V}$ を示した。このネコで は $2 \times \mathrm{N}_{1} \mathrm{~T}$ の刺激強度で外側核中央部に発生した $\mathrm{N}_{2}$ 波の振幅が $5 \times N_{1} T$ で発生した $N_{2}$ 波の振幅より大 きかったが，他の 2 匹のネコでは同様の現象はみられ なかった。 
A

B

C

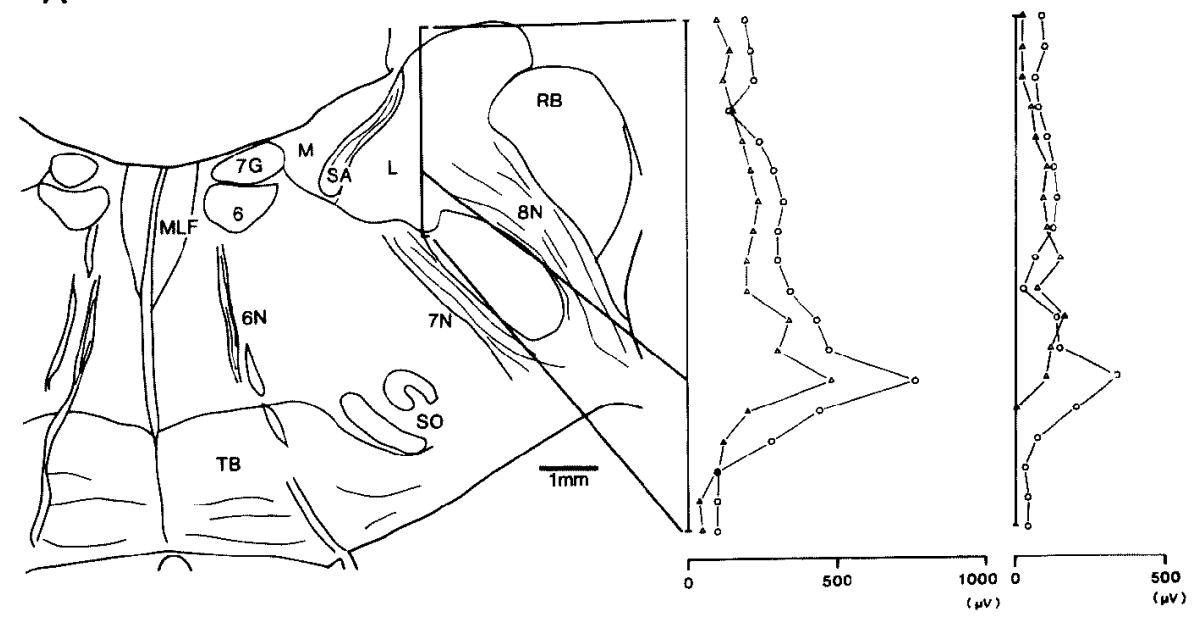

図 3 後半規管刺激により前庭神経外側核に発生する電場電位

$\mathrm{A}$ ：記録部位の組織図。䋛線は電極の刺入方向示す. 6 ：外転神経核,

$6 \mathrm{~N}$ ：外転神経， $7 \mathrm{G}$; 顔面神経㮏部， $\mathrm{L}$; 外側核, $\mathrm{M}$; 内側核, $\mathrm{ML}$

$\mathrm{F}$; 内側縦束, R B ; 索状体, S A ; 聴条, SO ; 上オリープ核, T B ; 台形体.

$\mathrm{B}: \mathrm{N}_{1}$ 波の振幅（横軸）と，電極の位置（維軸）との関係. 刺激強度は， 白丸が $5 \times N_{1} T$, 白三角が $2 \times N_{1} T$.

$\mathrm{C}: \mathrm{N}_{2}$ 波の振幅 (横軸) と, 電極の位置 (縦軸) との関係. 刺激強度はB と同し。.

A

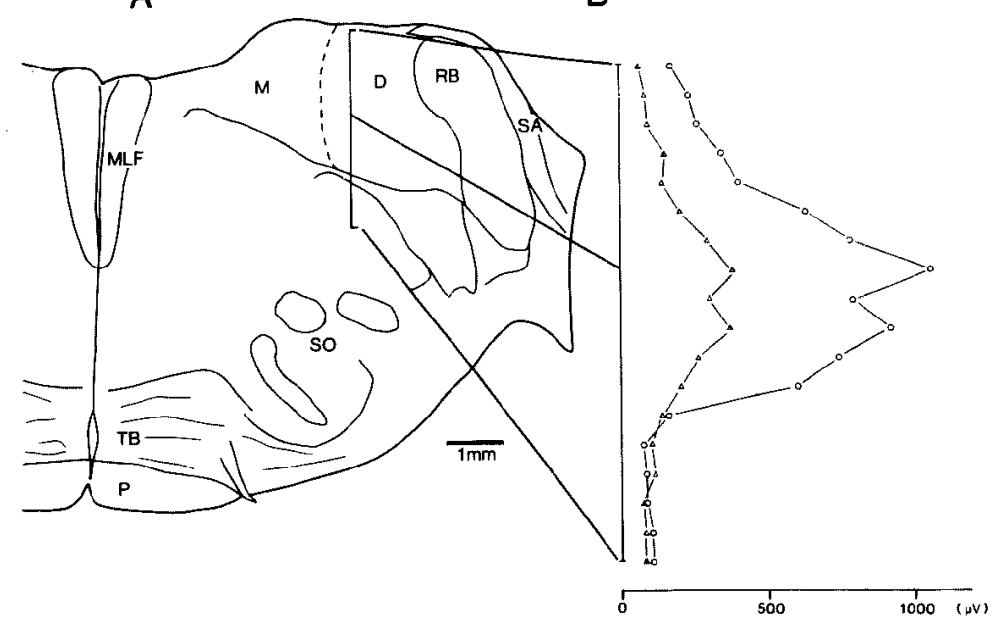

C

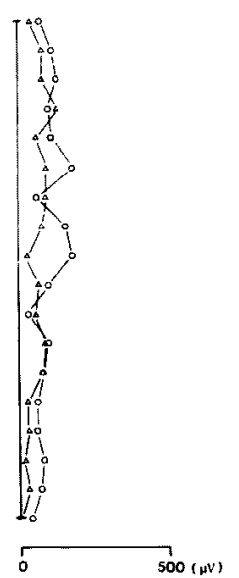

図 4 後半規管刺激により前庭神経下核に発生する電場電位

A：記録部位の組織図. 緹線は電極の刺入方向を示す。 $6 \mathrm{~N}$ ；外転神経,

$\mathrm{D}$; 下核, $\mathrm{M}$ ：内側核, ML F ; 内側綐束, $\mathrm{P}$; 錐体路, $\mathrm{R} \mathrm{B}$; 索状体, $\mathrm{SA} ;$ 聴条, SO； 上オリープ核, $\mathrm{T} \mathrm{B}$; 台形体.

$\mathrm{B}: \mathrm{N}_{1}$ 波の振幅 (横軸) と電極の位置 (縦軸) との関係. 刺激強度は, 白 丸が $5 \times N_{1} T$, 白三角が $2 \times N_{1} T$.

$\mathrm{C}: \mathrm{N}_{2}$ 波の振幅（横軸）と電極の位置（縦軸）との関係. 刺激強度は $\mathrm{B}$ と 同じ. 


\section{2）下核に発生する電場電位}

後半規管神経を $5 \times N_{1} \mathrm{~T}$ 及び $2 \times N_{1} \mathrm{~T}$ の強度で刺 激して発生した $\mathrm{N}_{1}$ 波の振幅を図 4-Bに示す. 背側部 ては $230 \mu \mathrm{V}$ であるが，腹側約 $1 / 3$ の部位で約 $1 \mathrm{mV}$ と 最大となり，さらに腹側に進むと，一度その振幅を減 ずるが再度約 $900 \mu \mathrm{V}$ となり，その後急速に振幅は減少 した. $2 \times \mathrm{N}_{1} \mathrm{~T}$ 刺激による振幅の推移も $5 \times \mathrm{N}_{1} \mathrm{~T}$ 刺激 と同様の傾向を示した.この例では $\mathrm{N}_{1}$ 波の振幅に 2 つのピークがあったが,この所見は一般的傾向とはい えず，他の例と共通する点は腹側部で最大の $\mathrm{N}_{1}$ 波が 記録できた点であった。

$\mathrm{N}_{2}$ 波については図 4-Cに示す. 後半規管神経を $5 \times N_{1} \mathrm{~T}$ で刺激すると，下核背側部で $110 \mu \mathrm{V}$ ，中央部 から腹側にかけて最大值 $180 \mu \mathrm{V}$ を示したが, その振幅 は $\mathrm{N}_{1}$ 波に比して小さい。また, $2 \times \mathrm{N}_{1} \mathrm{~T}$ の刺激強度で も同様に振幅は小さく, 背側部で $80 \mu \mathrm{V}$, 中央部から腹 側にかけて $130 \mu \mathrm{V}$ を示したのみであった。背側 $1 / 3 の$ 部位で $2 \times \mathrm{N}_{1} \mathrm{~T}$ の刺激強度で発生した $\mathrm{N}_{2}$ 波の振幅 が $5 \times \mathrm{N}_{1} \mathrm{~T}$ で発生した $\mathrm{N}_{2}$ 波より大きかったが，他の 5匹のネコではこのような現象はみられなかった。

3）内側核に発生する電場電位

後半規管神経を $5 \times \mathrm{N}_{1} \mathrm{~T}$ 及ぴ $2 \times \mathrm{N}_{1} \mathrm{~T}$ で刺激した ときに内側核に発生した $\mathrm{P}$ 波の振幅を図 $5-\mathrm{B}$ に示
す. $5 \times \mathrm{N}_{1} \mathrm{~T}$ の強度では背側部で $90 \mu \mathrm{V}$, 腹側に進むに 従って増大し, 核の中央部で $260 \mu \mathrm{V}$ と最大となり,そ の後は減少し核外に出る. $2 \times \mathrm{N}_{1} \mathrm{~T}$ の刺激強度でも同 様の推移を示した。

後半規管神経を $5 \times N_{1} \mathrm{~T}$ 及び $2 \times \mathrm{N}_{1} \mathrm{~T}$ で刺激した 時の $\mathrm{N}_{1}$ 波の振幅を図 5 -Cに示す. $5 \times \mathrm{N}_{1} \mathrm{~T}$ の刺激 で背側部では $120 \mu \mathrm{V}$ であり，中央部やや腹側で $460 \mu \mathrm{V}$ と最大值を示した。さらに腹側に進むと，振幅 は小さくなり核外に至ると急に小さくなる， $2 \times \mathrm{N}_{1} \mathrm{~T}$ の刺激強度でも背側部で $100 \mu \mathrm{V}$, 中央部やや腹側で $240 \mu \mathrm{V}$ と最大となり, $5 \times N_{1} \mathrm{~T}$ の結果と同様の推移で あった。

$\mathrm{N}_{2}$ 波の振幅も図 5-Dに示したように $\mathrm{N}_{\mathfrak{\imath}}$ 波と同 様の推移を示した。

4）上核に発生する電場電位

後半規管神経を $5 \times \mathrm{N}_{1} \mathrm{~T}$ 及び $2 \times \mathrm{N}_{\mathrm{t}} \mathrm{T}$ 刺激により 発生した $\mathrm{N}_{1}$ 波の振幅の大きさを図 $6-\mathrm{B}$ に示す. $5 \times$ $\mathrm{N}_{1} \mathrm{~T}$ の刺激を用いると背側部で $140 \mu \mathrm{V}$ であり，腹側 に進むに従い増大し，腹側約 $1 / 3$ 部位で $500 \mu \mathrm{V}$ と最 大值を示し，さらに腹側へ進むと急速に大きさを減じ ている. $2 \times \mathrm{N}_{1} \mathrm{~T}$ の刺激では背側部で $120 \mu \mathrm{V}$ であり, 腹側約1/3の部位では $5 \times N_{1} T$ のピークに一致して $440 \mu \mathrm{V}$ と最大值を示した。
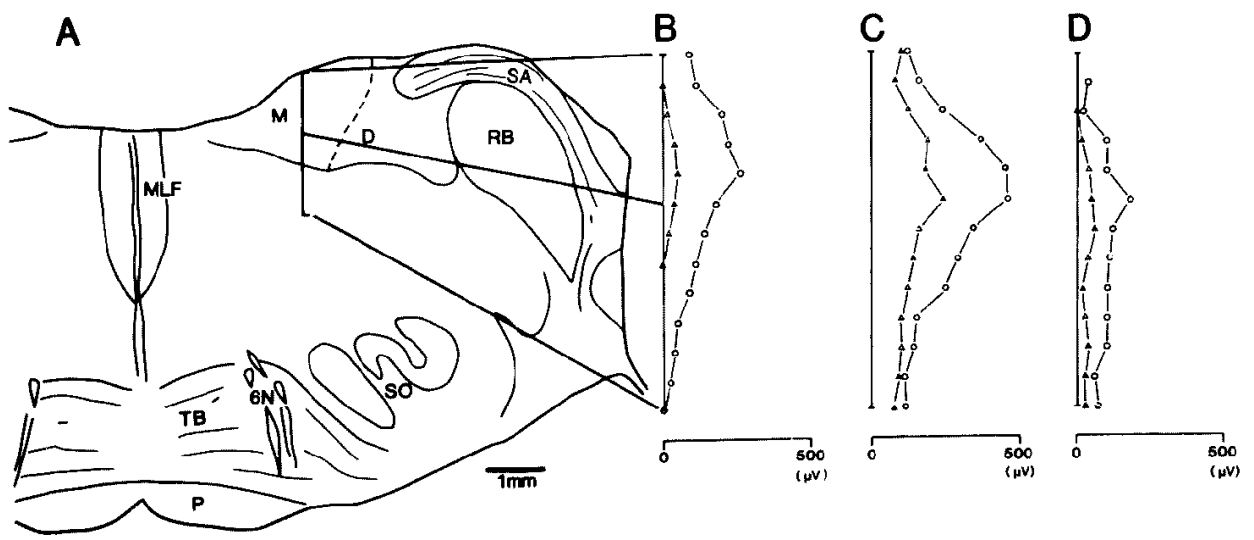

図 5 後半規管刺激により前庭神経内側核に発生する電場電位

$\mathrm{A}$ ：記録部位の組織図. 縦線は電極の刺入方向を示す. D; 下核, $\mathrm{M}$; 内 側核, ML F ; 内側緃束, $\mathrm{P}$; 錐体路, $\mathrm{R} \mathrm{B}$; 索状体, S A ; 聇条, S $\mathrm{O} ;$ 上オリーブ核, T B ; 台形体.

$\mathrm{B}$ ：P波の振幅 (横軸) と電極の位置（繸軸）との関係。刺激強度は，白 丸が $5 \times N_{1} T$ ，白三角が $2 \times N_{1} T$ 。

$\mathrm{C}: \mathrm{N}_{1}$ 波の振幅（横軸）の電極の位置（縦軸）との関係。刺激強度は $\mathrm{B}$ と 同じ.

$\mathrm{D}: \mathrm{N}_{2}$ 波の振幅（横軸）と電極の位置（縦軸）との関係. 刺激強度は $\mathrm{B}$ と 同じ. 

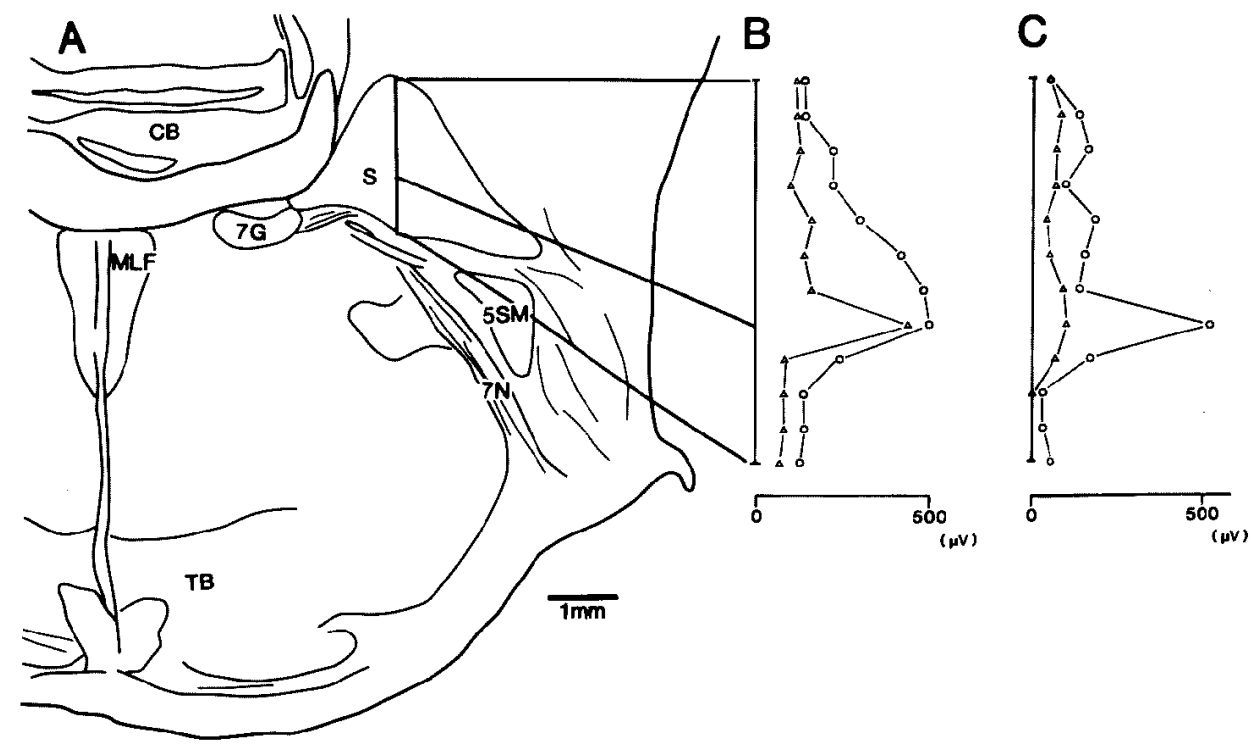

図 6 後半規管刺激により前庭神経上核に発生する電場電圧

A：記録部位の組織図. 縦線は電極の刺入方向を示す. $5 \mathrm{NM}$ ：三叉神経

沗髄路核， $7 \mathrm{G}$; 顔面神経膝部， $7 \mathrm{~N}$; 顔面神経, $\mathrm{C} \mathrm{B}$; 小脳, $\mathrm{MLF}$; 内側繸束, $\mathrm{S}$; 上核, $\mathrm{T} \mathrm{B}$; 台形体.

$\mathrm{B}: \mathrm{N}_{1}$ 波の振幅 (横軸) と電極の位置 (縦軸) との関係. 刺激強度は白丸 が $5 \times N_{1} T$, 白三角が $2 \times N_{1} T$.

$\mathrm{C}: \mathrm{N}_{2}$ 波の振幅（横軸）との関係, 刺激強度はBと同じ.

$\mathrm{N}_{2}$ 波については図 6-Cに示す.後半規管神経の $5 \times N_{1} T$ 刺激により背側部では $40 \mu \mathrm{V}, \mathrm{N}_{1}$ 波が最大值 を示した部位に一致して $520 \mu \mathrm{V}$ と最大となり,さらに 腹側では急激に小さくなっている。 $2 \times N_{1} \mathrm{~T}$ の刺激で は振幅はほとんど変化せず, $5 \times N_{1} \mathrm{~T}$ で最大值を示し た部位でも $100 \mu \mathrm{V}$ であった。これは $2 \times \mathrm{N}_{1} \mathrm{~T}$ の刺激 では発火しなかった多シナプス性前庭核ニューロンが $5 \times N_{1}$ Tで発火したことを示している。

また図 6ーAに示した部位よりもさらに吻側部で同 様の記録を行ったところ， $5 \times N_{1} \mathrm{~T}$ の刺激で $\mathrm{N}_{1}$ 波は 背側で $130 \mu \mathrm{V}$, 中央部でも $300 \mu \mathrm{V}$ と振幅を減じてお り， $\mathrm{N}_{2}$ 波も同様に小振幅であった。

4. $\mathrm{P}$ 波, $\mathrm{N}_{1}$ 波, $\mathrm{N}_{2}$ 波の潜時について

$\mathrm{P}$ 波の頂点は前庭神経核内における後半規管神経一 次求心性線維の最大興奮時をあらわし， $\mathrm{N}_{1}$ 波の始ま りは前庭二次ニューロンのうち最も早く放電したグル ープの発火潜時を示し, 同波の頂点は二次ニューロン 群の最大放電を意味している， $\mathrm{N}_{2}$ 波の成因について は後述する．後半規管神経刺激により発生するP波, $\mathrm{N}_{1}$ 波， $\mathrm{N}_{2}$ 波の潜時を始まりと頂点とに分け，各々の 潜時の平均士標準偏差 (Mean士S.D.) を表 1 に記載し
表 1 後半規管神経刺激により各亜核に 発生する電場電位の潜時

\begin{tabular}{cccccc}
\hline & P 波 & \multicolumn{2}{c}{$\mathrm{N}_{1}$ 波 } & \multicolumn{2}{c}{$\mathrm{N}_{2}$ 波 } \\
& Peak & Initiation & Peak & Initiation & Peak \\
\hline 内側核 & 0.53 & 0.90 & 1.18 & 1.81 & 2.14 \\
$(\mathrm{n}=8)$ & \pm 0.08 & \pm 0.19 & \pm 0.18 & \pm 0.20 & \pm 0.20 \\
$\mathrm{~T}$ 核 & 0.46 & 0.73 & 1.01 & 2.01 & 2.24 \\
$(\mathrm{n}=10)$ & \pm 0.05 & \pm 0.08 & \pm 0.11 & \pm 0.20 & \pm 0.20 \\
外側核 & 0.48 & 0.74 & 0.94 & 1.83 & 2.10 \\
$(\mathrm{n}=5)$ & \pm 0.05 & \pm 0.05 & \pm 0.05 & \pm 0.25 & \pm 0.30 \\
上 核 & 0.65 & 0.97 & 1.30 & 1.97 & 2.20 \\
$(\mathrm{n}=3)$ & \pm 0.07 & \pm 0.21 & \pm 0.10 & \pm 0.25 & \pm 0.20 \\
\hline
\end{tabular}

Initiation: 各波の始まり Peak : 各波の頂点 単位: ms た。

各々の值について四严核間に打る有意差の検定を 一元配置分散分析法（F-検定法）を用いて行った。 F 一検定法で有意差を認めたものについては,各重核間て の比較のためにさらに全体有意差法を用いて有意差を 検定した。 
$\mathrm{P}$ 波の頂点まで潜時は，上核で他の三亜核よりも 有意に遅かった $(\mathrm{p}<0.01)$.

$\mathrm{N}_{1}$ 波の始まりまでの潜時についてみると，上核で は下核，外側核よりも有意に遅かった $(\mathbf{p}<0.01) . \mathrm{N}_{1}$ 波の頂点までの潜時では, 上核は下核と外側核よりも 有意に遅く $(\mathrm{p}<0.01)$ ，内側核は外側核よりも有意に 痋かった $(\mathrm{p}<0.05)$.

$\mathrm{N}_{2}$ 波の始まりまでの潜時及び $\mathrm{N}_{2}$ 波の頂点までの 潜時については, $\mathrm{p}>0.25 て ゙$ 有意の差を認めなかった。

\section{考察}

今回の実験は後半規管神経を選択的に電気刺激し, 前庭神経四垔核からの現象を記録したものであるが， この種の実験における半規管神経選択的電気刺激で は，つねに電流滑走を考慮にいれなければならない. その理由は各々の半規管神経と耳石器神経の距離が近 いからである. しかし図一 2 の成績からみて, 後半規 管神経を $2.5 \times \mathrm{N}_{1} \mathrm{~T}$ 前後の刺激強度で刺激した場合, 他の半規管への電流滑走はないか非常に弱いと考えら れた。この実験ては後半規管神経と他の半規管神経を 同時に刺激した場合に発生する $\mathrm{N}_{1}$ 波の振幅が各々の 半規管神経を選択的に刺激したときに発生する $N_{1}$ 波 の振幅の算術和にほほ等しいことを示している.また，

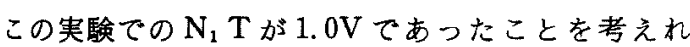
代,後半規管神経を $2.5 \mathrm{~V}$ 前後以下で刺激した場合, 他 の神経への電流滑走は起こりにくいと考えられる. $3 \times$ $\mathrm{N}_{1} \mathrm{~T}(3.0 \mathrm{~V})$ 以上の刺激では後半規管神経と他の半規 管神経の同時刺激により発生する $N_{1}$ 波の振幅は選択 的電気刺激による N1 波の算術和よりやや小さく，後 半規管神経刺激時に，他の半規管神経に電流滑走を起 こしている可能性は強いが，図 3 から図6で用いたネ コに拄る $\mathrm{N}_{1} \mathrm{~T}$ は $0.5 \mathrm{~V} て ゙, 5 \times \mathrm{N}_{1} \mathrm{~T}$ としても $2.5 \mathrm{~V}$ でり，前述した事柄を考慮にいれれば電流滑走の存 在は少ないといえる。

一方, 耳石器系への電流滑走も考えなければならな

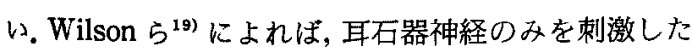
場合, 前庭神経核に発生する電場電位は $\mathrm{P}$ 波がはっき りせず， $\mathrm{N}_{1}$ 波の振幅も小さく（前庭神経刺激時の約 $1 / 10), \mathrm{N}_{1}$ 波の潜時も始まりで $0.7 \sim 1.9 \mathrm{~ms}$, 頂点で も1. 2 2. $5 \mathrm{~ms}$ と遅く, 今回の実験での潜時と著しく 異なり，また，潜時の明瞭な $\mathrm{N}_{2}$ 波は認められないとい う.これらのことから耳石器神経への電流滑走はあっ ても今回の実験結果をゆがめる危惧は少ないと考えら れる。
銀ボール電極で前庭神経を刺邀した場合の $\mathrm{N}_{1}$ 波の 振幅の最大值は内側核と, 下核の境界部周辺で $2.0 \mathrm{mV}$ 以上であった ${ }^{11)}$. 本実験では $\mathrm{N}_{1}$ 波が最大を示したの

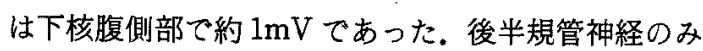
を選択的に刺激した時の $\mathrm{N}_{1}$ 波の振幅が小さかった最 大の原因は，後半規管神経刺激に応答するニューロン の数がすべての前庭神経を銀ボール電極で刺激した時 に応答するニューロンよりも少ないためと考察され る.

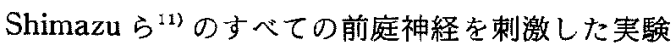
では $\mathrm{N}_{2}$ 波の振幅はおよそ $800 \mu \mathrm{V}$ と $\mathrm{N}_{1}$ 波の振幅の 約1/3であった。本赛験の後半規管神経選択的刺激にお いては $\mathrm{N}_{2}$ 波の振幅はそのほとんどが $\mathrm{N}_{1}$ 波の振幅の 1/4以下であった. $\mathrm{N}_{2}$ 波は前庭核ニューロンの多シナ プス性の活動, 前庭二次ニューロンの 2 発発射, 耳石 器系ニューロンの活動により発生する $\mathrm{N}_{1}$ 波等が主な 構成要素であることから, $\mathrm{N}_{2}$ 波の振幅が小さいとい うことは後半規管神経より多シナプス性に入力を受け る前庭核ニューロンの数が少ないか, 後半規管神経入 力を受ける前庭二次ニューロンの内， 2 発発射をする ニューロンが少ないか, 後半規管神経入力を受ける抑 制性前庭二次二ューロンの活動が多シナプス性ニュー ロンの活動を抑制するのか, 耳石器系の $\mathrm{N}_{1}$ 波の成分 がないためかなどいくつかの理由が考察された。また， Shimazu らの実験 ${ }^{11)}$ と本実験とは麻酔条件が異なっ ているが, Pentobarbital 麻酔の細胞外電場電位への 影響は $\mathrm{N}_{1}$ 波よりも $\mathrm{N}_{2}$ 波が影響を受けやすい゙けい う報告もみられ，麻酔による影響も考虑に入れなけれ ばならない。

本実験に基づく結果のいくつかを勘考すれば，後半 規管神経の刺激強度を徐々に強くしていくと， $\mathrm{N}_{1} \mathrm{~T}$ の $4 \sim 5$ 倍の刺激で各電場電位の振幅が飽和してお $\eta$, Shimazu and Precht ${ }^{10)}$ 及び, Uchino $ら^{15)} の$ 前庭 一次求心性線維刺激のそれとよく一致している。 また 図1に示したP波の最大振幅が小さいが，これは記録 部位が内側核であり，一次求心性線維の主たる投射部 位より遠位で記録したためと考えている。

次に前庭神経四亜核における結果をみると，外側核 では背側より腹側に進むに従い， $\mathrm{N}_{1}$ 波の振幅は增大 し, $\mathrm{N}_{2}$ 波の振幅も同様の傾向を示した.この実験では 刺激強度と振幅の大きさがほぼ相関しているが，外側 核中央部に発生した $\mathrm{N}_{2}$ 波では $2 \times \mathrm{N}_{1} \mathrm{~T}$ の刺激のほ うが $5 \times N_{1} \mathrm{~T}$ の刺激よりも大きな振幅を示した.これ は $\mathrm{N}_{1}$ 波に含まれる抑制性前庭二次ニューロンの関与 
も考えなくてはならない。

下核，内側核，上核においても背側より腹側に進む につれ最大振幅を示し, 各亜核の中央部から腹側部に 後半規管神経から単シナプス性及び多シナプス性に入 力を受ける前庭核ニューロンが存在することを示して いる。

また，上核では後半規管神経からの投射が吻側より も尾側に密であるという Mannen ら") の HRP 注入に よる形態的研究と, 著者の電気生理学的実験の結果は 一致していた。

後半規管神経の電気刺激をしたときに各亜核で記録 された電場電位の潜時をみると, Precht and Shimazu")の結果とほぼ同様の結果が得られた。上核 で記録した $\mathrm{P}$ 波の頂点までの潜時は，他の三亜核で記 録した潜時に比べ有意に遅かった $(\mathrm{p}<0.01)$ 。この結 果加, 前庭一次求心性線維の前庭神経核内にちける 上行枝の伝導速度が下行枝の伝導速度より遅い，すな わち下行枝のほうが上行枝に比して太い可能性が考え られる。

$\mathrm{N}_{1}$ 波の始まりまで及び頂点までの潜時について， 上核は，下核と外側核よりも有意に遅かった（ $\mathrm{p}<$ 0.01).このことも一次求心性線維の上行枝の伝導速度 が遅いことがその最大の要因と考えられる．内側核で 記録された $\mathrm{N}_{1}$ 波の頂点までの潜時は外側核のそれよ りも有意に遅かった $(\mathrm{p}<0.05)$ ．これは内側核の二次 ニューロン群の最大放電が外側核のそれより遅いこと を示し，これを形態学的に推論すれば，内側核への側 枝が外側核への側枝より細いことが想像できる。

前, 外側半規管由来の前庭一次求心性線維の分布に 比べ, 後半規管由来の前庭一次求心性線維は前庭神経 核の中央部に分布している 軸索内注入の結果を考慮に入れながら四要核内の $26 力$ 所以上で電場電位を記録した。記録を行った範囲内で は Mannen ら ${ }^{8)}$ の前述した実験結果を良く表付ける ものであった。

\section{まとめ}

後半規管神経を電気刺激すると, 前庭四重核, すな わち上核・内側核・下核・外側核に，前庭一次求心性 線維の興奮による $\mathrm{P}$ 波, 前庭二次ニューロンの放電に よる $\mathrm{N}_{1}$ 波，つづいておこる $\mathrm{N}_{2}$ 波が発生した.

$\mathrm{P}$ 波の振幅の最大值は内側核， $\mathrm{N}_{1}$ 波の振幅の最大 值は下核腹側部に見られ， $\mathrm{N}_{2}$ 波の振幅の最大值は上 核で記録された。
後半規管入力を受ける前庭核ニューロンは四亜核と も腹側に多く，特に二次ニューロン群は下核に最も多 いと考えられた。

$\mathrm{P}$ 波の潜時加前庭一次求心性線維の前庭神経核内 の上行枝は下行枝に比して遅く，上行枝は細いと考え られた。

内側核及び外側核で記録された $N_{1}$ 波の頂点まての 潜時から，内側核への側枝が外側核への側枝より細い ことが推察された。

\section{参考文献}

1) Brodal A, Pompeiano $O$ and Walberg F : The vestibular nuclei and their connections anatomy and functional correlations. Edinburgh and London, Oliver and Boyd, 1962.

2) Cohen B, Suzuki J-I and Bender MB : Eye movements from semicircular canal nerve stimulation in the cat. Ann Otol (St. Louis) 73: 153-170, 1964.

3) Gacek RR: The course and central termination of first order neurons supplying vestibular endorgans in the cat. Acta Oto-laryngol Suppl 254: 1-66, 1969.

4) Ishizuka N, Sasaki S-I and Mannen H: Central course and terminal arborization of single primary vestibular afferent fibers from the horizontal canal in the cat. Neurosci Letts 33: 135-139, 1982.

5) Korte GE: The brainstem projection of the ves tibular nerve in the cat. J Comp Neurol $184: 279$ $-292,1979$

6) Korte GE and Friedrich Jr VL: The fine structure of the feline superior vestibular nucleus: identification and synaptology of the primary vestibular afferents. Brain Res 8: 65-96, 1968.

7) Lang $W$ and Kubik $S$ : Primary vestibular afferent projections to the ipsilateral abducense nucleus in the cat. An autoradiographic study. Exp Brain Res 37 : 177-181, 1979.

8) Mannen H, Sasaki S-I and Ishizuka N : Trajectory of primary vestibular fibers originating from the lateral, anterior, and posterior semicircular canals in the cat. Proc Japan Acad 58: 237-242, 1982.

9) Precht $W$ and Shimazu $H$ : Functional connections of tonic and kinetic vestibular neurons with primary vestibular afferents. J Neurophysiol 28: 1014-1028, 1965.

10) Shimazu $H$ and Precht $W$ : Tonic and kinetic 
responses of cat's vestibular neurons to horizontal angular accelation. J Neurophysiol 28: 991-1013, 1965.

11) Shimazu $H$ and Precht $W$ : Inhibition of central vestibular neurons from the contralateral labylinth and its mediating pathway. J Neurophysiol 29 : 467-492, 1966.

12) Stein BM and Carpenter MB : Central projections of portions of the vestibular ganglia innervating specific parts of the labyrinth in the rhesus monkey. Am J Anat 120: 281-318, 1967.

13) Suzuki J-I, Cohen B and Bender MB: Compensatory eye movements induced by vertical semicircular canal stimulation. Exp Neurol 9: 137-160, 1964.

14) Thomas RC and Wilson VJ : Presice localization of Renshaw cells with a new marking technique. Nature 206: 211-213, 1965.

15) Uchino $Y$, Kudo N, Tsuda $K$ and Iwamura $Y$ : Vestibular inhibition of sympathetic nerve activities. Brain Res 22: 195-206, 1970.

16) Uchino $Y$, Hirai $N$ and Watanabe $S$ : Vestibuloocular reflex from the posterior canal nerve to extraocular motoneurons in the cat. Exp Brain Res 32 : 377-388, 1978.

17) Walberg F, Bowsher D and Brodal A: The termination of primary vestibular fibers in the vestibular nuclei in the cat. An experimental study with silver method. J Comp Neurol 110: 391-419, 1958.

18) Wilson VJ, Gacek RR, Maeda $M$ and Uchino $Y$ : Saccular and utricular input to cat neck motoneurons. J Neurophysiol 40:63-73, 1977.

19) Wilson VJ, Gacek RR, Uchino $Y$ and Susswein AJ : Properties of central vestibular neurons fired by stimulation of the saccular nerve. Brain Res 143: 251-261, 1978.

稿を終えるにあたり，御指導, 御校閲を頂いた聖マリアン 十医科大学聂鼻咽喉科学教室竹山勇主任教授, 加藤功教授, 並びに本実験の機会をあたえて頂いた聖マリアンナ医科入 学第一生理学教室冨田恒男客員教授, 豊田順一主任教授に 深謝致します。

また本実験を直接御指導頂いた杏林大学医学部第一生理 学教室内野善生助教授（現東京医科大学第二生理学教室教 授)，航空宇宙技術研究所計測部井須尚紀主任研究官，実験 の介助をして頂きました杏林大学医学部第一生理学教室実 験助手市川利信氏, 飯澤みゆき氏, 聖マリアンナ医科大学耳 鼻咽喉科教室佐藤成樹先生に感謝致します。

最後に本実験を行うにあたり多方面にわたり御便宜を賜 わりました聖マリアンナ医科大学耳鼻咽喉科教室教室員各 位に厙く御礼申し上げます。

(原稿受付 昭和63.3.30日念載)

別刷請求先 $=213$ 川崎市宮前区菅生2-16-1 聖マリアンナ医科大学耳鼻咽喉科学教室 中島博昭 